УДК 331.108.24:004[37.015.6]

\title{
УПРАВЛІННЯ ПЕРСОНАЛОМ В ЕПОХУ ЦИФРОВОЇ ЕКОНОМІКИ
}

\section{HUMAN RESOURSE MANAGEMENT IN THE DIGITAL ECONOMY}

\author{
Збрицька Тетяна Петрівна \\ кандидат економічних наук, доцент, \\ Одеський національний економічний університет \\ ORCID: https://orcid.org/0000-0002-3558-1795 \\ Сорока Олександра Володимирівна \\ кандидат економічних наук, доцент, \\ Одеський національний економічний університет \\ ORCID: https://orcid.org/0000-0001-6982-1817
}

\author{
Zbritskaya Tatiana, Soroka Alexandra \\ Odessa National Economic University
}

\begin{abstract}
Автори аналізують основні тенденції в сфері управління людськими ресурсами в умовах цифрової економіки. Швидка транссрормація цифрових технологій, економічних і соціальних умов та економіка знань, гостро ставлять питання про перегляд важливих аспектів управління людським капіталом. Мова йде не тільки про підвищення вимог до працівників компаній у зв'язку з впровадженням високотехнологічних продуктів, а й про зміну у відповідь на нові запити бізнесу моделі управління персоналом. HR-менеджери повинні володіти сучасними технологіями і одночасно трансформувати базові HR-процеси, підходячи по-новому до питань підбору персоналу, управління талантами, корпоративного навчання, практичної реалізації людського інтелекту тощо. Перехід на роботу з персоналом в цифровому форматі включає в себе безліч варіантів взаємодії роботодавців з працівниками, платсрорм та інструментів для побудови гнучких організацій і створення робочих місць нового типу.
\end{abstract}

Ключові слова: управління персоналом, цифрові технології, цифррова економіка, чат-боти, людські ресурси, економіка знань.

Авторы анализируют основные тенденции в сфере управления человеческими ресурсами в условиях цифровой экономики. Быстрая трансформация цифровых технологий, экономика знаний, остро ставит вопрос о пересмотре важных аспектов управления человеческим капиталом. Речь идет не только о повышении требований к работникам компаний в связи с внедрением высокотехнологичных продуктов, но и об изменении в ответ на новые запросы бизнеса модели управления персоналом. HR-менеджеры должны владеть современными технологиями и одновременно трансформировать базовые HR-процессы, подходя по-новому к вопросам подбора персонала, управления талантами, корпоративному обучению, практической реализации человеческого интеллекта и т.д. Переход на работу с персоналом в цифровом фрормате включает в себя множество вариантов взаимодействия работодателей с сотрудниками, платорорм и инструментов для построения гибких организаций и создания рабочих мест нового типа.

Ключевые слова: управление персоналом, цифровые технологии, цифровая экономика, чат-боты, человеческие ресурсы, экономика знаний.

Promotion of digital technologies in the XXI century. requires cardinal transformations of business processes in all spheres of social and economic life. Digital transformations are of particular relevance in the field of HRM (human resource management), which contribute not only to increasing labor productivity, but also to the development of talents. The authors analyze the main trends in human resource management in the digital economy. The rapid transformation of digital technologies, economic and social conditions, the knowledge economy, sharply raises the question of revising the fundamental aspects of human capital management. It is not only about increasing requirements for company employees in connection with the introduction of high-tech products, but also about changing the personnel management model in response to new business requests. HR Managers Must be proficient in modern technology while simultaneously transforming the underlying HR processes by taking a fresh approach to recruiting, 
talent management, corporate training, and more. Moving to digital workforce includes many options for employers to interact with employees, platforms and tools for building agile organizations and creating new types of jobs. The article analyzes the current global economic and technological trends affecting the transformation of the labor market and the formation of new socio-economic relations in the context of the formation of the digital economy. The authors draw attention to the change in the nature of labor and forms of labor activity, requirements for professional skills. It is shown how the changes associated with the digitalization of the economy directly affect the issues of human resource management. The process of information transformations is investigated, attention is focused on the importance of personnel in the digital development of an organization. The role of the use of information and digital technologies in the personnel management system is determined. Some technologies that give domestic companies new opportunities for the further development of personnel management are considered. Also examples of the use of technologies and the benefits that a company can get by starting to implement them are given.

Keywords: personnel management, digital technologies, digital economy, chatbots, human resources, knowledge economy.

Постановка проблеми В умовах розвитку процесів глобалізації, для яких характерне прискорення світового обороту товарів і послуг, гострота конкурентної боротьби перманентно зростає. В цьому контексті додаткові конкурентні переваги отримують фрірми, здатні сорормувати ефрективну управлінсько-адміністративну систему, що дозволяє швидко реагувати на зміни зовнішнього і внутрішнього середовища організації. На нашу думку, невід'ємним елементом подібної системи є HR-служба господарюючого суб'єкта, що відповідає, в цілому, за розвиток людського капіталу фрірми. В умовах високої конкуренції персонал $€$ головним суб'єктомоб'єктом управління, що володіє стратегічним значенням.

Новий тип економіки, котрий є результатом еволюційного розвитку економічних систем, а конкретно - базисом іï виступає сорормована національна інноваційна система, що сприяє розвитку усіх сорер матеріального й нематеріального виробництва на основі прирощення та оновлення знань, у результаті чого у складі виробленої продукції (послуги) зростає частка доданої вартості за рахунок інтелектуальної складової та змінюється характер людської праці на користь творчої та інтелектуальної діяльності. Це економіка, основою якої є високопродуктивні, конкурентоспроможні робочі місця, які посідають висококваліфіковані, інноваційно-орієнтовані працівники; в якій впроваджуються інформаційні, комунікаційні та інші сучасні прогресивні технології і виготовляється високотехнологічна, наукоємна та конкурентоспроможна продукція. Цисррові транссрормації, що відбуваються в економіці, відкривають можливості для модернізації технологій роботи з персоналом, що може значно підвищити есрективність діяльності підприємства.

3 урахуванням вищевикладеного, актуальними і своєчасними є роботи, присвячені транссрормації срункціоналу кадрової служби на мікроекономічному рівні із застосуванням цифррового інструментарію.

Аналіз останніх досліджень і публікацій. Дослідженню різноманітних тенденцій щодо удосконалення діяльності у сфері управління персоналом присвячено роботи багатьох українських та закордонних вчених, зокрема Данюка В., Жуковської В., Куйбіди В., Січкаренко К., Семенчук О., Гвеноле Н., Кеннеді Е., Нагибіної Н., Санд Р. та інших. Разом з тим, трансорормація технологій управління персоналом під впливом оновлення знань щодо можливостей цифрової економіки все більше пришвидшується, що вимагає більш глибокого вивчення, систематизації та оцінки, a також визначення напрямів поширення і застосування цифррового HR у діяльності вітчизняних підприємств з урахуванням передових інформаційних технологій.

Виділення не вирішених раніше частин загальної проблеми. Шляхом аналізу та порівняння вже існуючих підходів до управління персоналом та їх ефективності можна зробити висновок, що стандартні методи, звичайно, працюють, проте займають набагато більше часу та мають нижчу результативність за сучасні методи, які застосовуються при digital-можливостях. На жаль, величезна кількість компаній і рекрутингових агенцій не обізнані про широкі можливості застосування новітніх технологій для рекрутингу персоналу i, тим самим, втрачають час, а можливо, найкращих працівників. На сьогодні тема digitalможливостей у царині рекрутингу персоналу $\epsilon$ недостатньо дослідженою на теренах України, особливо порівняно з іншими країнами. Незважаючи на велику кількість робіт, що розкривають різні аспекти технологій управління персоналу, питання запровадження digital-технологій у сучасну вітчизняну практику управління людськими ресурсами залишається до кінця не дослідженою. 
Формулювання цілей статті (постановка завдання). Метою наукового дослідження передбачено опрацювання особливостей і тенденцій управління людськими ресурсами та їхньої творчої й інтелектуальної діяльності в умовах глобальної цифрровізації економіки.

Виклад основного матеріалу дослідження. Цисррова економіка $€$ природним наслідком технічного прогресу, розвиток технологічної інфрраструктури та застосування великих баз даних викликали масштабну цифррову трансформацію суспільства. XXI століття - це епоха активного розвитку цисррових технологій і комунікаційних технологій, мережі Інтернет, сорери IT, і характеризується, в основному, цифровізацією і автоматизацією всіх процесів, які можна автоматизувати.

«Цифрова економіка» почала свій розвиток 3 цифррової революції, яка представляє собою перехід від механічної і аналогової електронної технології до цифрової електроніки. Багато вчених і публіцистів характеризують це поняття по-різному: одні називають її новою економікою, інші інтернет-економікою.

Цифррова економіка - це сукупність відносин, що складаються в процесах виробництва, розподілу, обміну та споживання, заснованих на онлайн-технологіях і спрямованих на задоволення потреб у життєвих благах, що, в свою чергу, передбачає формування нових способів і методів господарювання і вимагає дієвих інструментів державного регулювання [1].

В одній з доповідей Світового банку взагалі зазначено, що поняття «цифрова економіка», представлене в широкому сенсі, являє собою величезну систему економічних, соціальних і культурних відносин, які грунтуються на використанні цифрових технологій. Але більш правильне поняття можна дати таке, що цифррова економіка $\epsilon$ економікою інновацій, що здійснює свій розвиток за допомогою впровадження нових технологій» [2, с. 5].

Циоррова економіка фрормує новий тип організації - це цисррова організація (підприємство). Незважаючи на новизну поняття, циорове підприємство має широку інтерпретацію. Так, на думку М.В. Баранова, концепція цисрового підприємства передбачає перебудову бізнесу, включаючи виробництво, відносини 3 клієнтами, методи управління компанією, на основі широкого застосування цифрових технологій.

Основними тенденціями формування цифррового підприємства поряд 3 оптимізацією управління внутрішніми процесами на основі ERP, BPM і ESM-систем і аналізу великих даних $€$ забезпечення мобільності всіх співробітників підприємства, соціальність, управління знаннями та людьми i, як наслідок, зміна організаційної структури, культури, сприйняття змін, зміна компетенцій персоналу і системи управління в цілому.

В якості основних цінностей цифррової економіки виступають інорормація та знання, джерелом і носієм яких є людина, тому цифрова економіка визначає нову роль людських ресурсів і людського капіталу, а не тільки постійні зміни і тенденції різних інновацій. Розвиток економіки знань слугує найважливішою умовою для становлення інфрормаційного суспільства, що створює, розповсюджує та використовує знання для забезпечення свого зростання та конкурентоспроможності. До цього поняття відносять: ссреру освіти, досліджень і розробок, зв'язок, інфрормаційну діяльність та новітніх технологій, використання інорормації та знань, що зосереджені в людському капіталі. Це нові знання, які генеруються наукою, підготовка високоякісного людського капіталу на базі якісної освіти, створення додаткових багатств виробничим сектором і бізнесом.

Незважаючи на всі досягнення в автоматизації бізнес-процесів, люди з їх інтуїцією, знаннями, вміннями і навичками залишаються ключовим фрактором успіху цифррового підприємства, тому традиційні системи управління кадрами трансформуються в управління талантами, навчанням і розвитком творчої та інтелектуальної діяльності персоналу. У зв'язку з цим необхідно розглянути особливості нових умов, що формуються і визначити цілі, завдання, функції та ролі людини в системі управління. Отже, у зв'язку з цифрровізацією економіки в силу вступають нові тенденції в сорері управління персоналом.

У таблиці 1 авторами складено огляд найпоширеніших глобальних трендів, грунтуючись на публікаціях з цього питання.

Із табл. 1 видно, що HR-тренди є частиною тенденцій і течій, що створюються під впливом інтенсивної цифровізації ринку і всього економічного простору. Це можна пояснити тим, що автоматизація будь-яких процесів, що відбуваються в економіці, так чи інакше пов'язана зі змінами на ринку праці. В кінцевому підсумку, основний двигун цифровізації - це люди, творці і разом з тим користувачі цифрових технологій. Закономірно, що цифрровізація насамперед пов'язана саме зі ссрерою управління персоналом, і лише слідом через неї - з іншими сорерами.

Радикальні зміни в цифррову епоху змінюють профріль управління персоналом. Digital 
Таблиця 1

\section{Глобальні тренди цифровізації та HR-тренди}

\begin{tabular}{|c|c|c|}
\hline \multicolumn{2}{|r|}{ Тренд } & Зміст \\
\hline \multirow{4}{*}{ 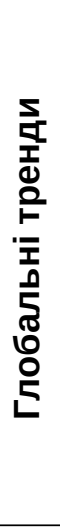 } & \begin{tabular}{|l} 
Глобалізація в \\
сорері цифррової \\
індустрії
\end{tabular} & $\begin{array}{l}\text { Технології можуть бути однаково затребувані у всіх куточках світу, що } \\
\text { породжує до них інтерес інвесторів з різних країн. При цьому вітчизняні } \\
\text { компанії все більше вбудовуються в міжнародні альянси, створюючи } \\
\text { партнерські відносини }\end{array}$ \\
\hline & $\begin{array}{l}\text { Цифрровізація } \\
\text { державних } \\
\text { послуг }\end{array}$ & $\begin{array}{l}\text { Держава стимулює бізнес до того, щоб впроваджувати високотехнологічні } \\
\text { процеси, з іншого - вона є активним споживачем нових технічних розробок } \\
\text { і цифрових рішень. }\end{array}$ \\
\hline & Цифррова етика & $\begin{array}{l}3 \text { кожним роком присутність в соціальних мережах стає все більш і більш } \\
\text { витратною з точки зору часу. Поступово кожен стає не тільки споживачем, } \\
\text { але і постачальником інфрормаційного контенту в мережах, що накладає } \\
\text { певну відповідальність. }\end{array}$ \\
\hline & HR Digital & $\begin{array}{l}\text { Цей глобальний тренд, що позначає перехід до діджиталізації, є новим } \\
\text { етапом розвитку HR-галузі та виводить роботу НR-ів на новий рівень } \\
\text { менеджменту, де вони повинні застосовувати сучасні digital-інструменти }\end{array}$ \\
\hline \multirow{6}{*}{ 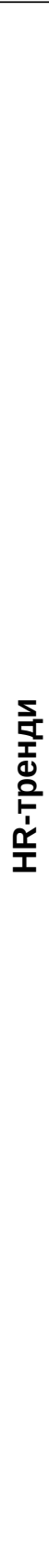 } & $\begin{array}{l}\text { Затребуваність } \\
\text { аутсорсингу }\end{array}$ & $\begin{array}{l}\text { Це передача неосновних, але важливих процесів компанії зовнішнім } \\
\text { виконавцям. Сучасний світ стрімко змінюється. З'являється багато нової } \\
\text { інорормації, в якій потрібно вміти розбиратися. Тому сьогодні компанії } \\
\text { більше зацікавлені в аутсорсингу, а глибина пенетраці провайдера у } \\
\text { внутрішні процеси компанії стає вагомішою. Вже недостатньо виконувати } \\
\text { адміністративну, кадрову та бухгалтерську роботу. Цими процесами } \\
\text { потрібно управляти. }\end{array}$ \\
\hline & $\begin{array}{l}\text { Нові моделі } \\
\text { кар'єри }\end{array}$ & $\begin{array}{l}\text { На практиці з'являється все більше прикладів того, як кандидатів } \\
\text { вибирають з використанням тестового завдання або використовують } \\
\text { елементи геймісрікації для залучення і відбору. У таких випадках має } \\
\text { значення лише те, що кандидат вміє і як саме він виконує цю роботу. } \\
\text { Резюме в такому випадку може не знадобитися зовсім }\end{array}$ \\
\hline & HR-маркетинг & $\begin{array}{l}\text { Інструменти, які використовуються в маркетингу, плавно переходять і в } \\
\text { сфреру НR. Наприклад, досвід клієнта класично вивчали маркетологи, } \\
\text { а сьогодні будь-який HR вивчає шлях кандидата і шлях співробітника. І } \\
\text { починається цей шлях задовго до того, як людина приходить на співбесіду. } \\
\text { Він бачить інорормацію про компанію в відкритих джерелах, в соцмережах, } \\
\text { чує від знайомих, читає відгуки. Це все орормує точки вражень, які } \\
\text { впливають на його вибір. Навіть в той момент, коли співробітник залишає } \\
\text { компанію, ця точка не стає останнью. Колишній співробітник може } \\
\text { продовжувати купувати продукцію компанії, рекомендувати друзям роботу } \\
\text { в ній або стати діловим партнером. }\end{array}$ \\
\hline & $\begin{array}{l}\text { Автоматизація в } \\
\text { HR: чат-боти } \\
\text { і відео-інтерв'ю }\end{array}$ & $\begin{array}{l}\text { Технології найбільш ефективні тоді, коли вони доповнюють людей, а } \\
\text { не замінюють їх. Чат-бот (програма, яка імітує поведінку людини при } \\
\text { спілкуванні з користувачем, виконуючи дії, закладені алгоритмом) спрощує } \\
\text { процес пошуку і підбору для всіх учасників. Відео-інтерв'ю як інструмент } \\
\text { підбору активно використовують НR багатьох компаній. Відео-інтерв'ю не } \\
\text { замінює особистої бесіди, але стає першим етапом відбору } \\
\end{array}$ \\
\hline & $\begin{array}{l}\text { Формування } \\
\text { культури } \\
\text { навчання }\end{array}$ & $\begin{array}{l}\text { Компетенції сьогодні зростають повільніше, ніж того вимагає ринок. } \\
\text { Передові компанії перетворюють кар'єру і можливості навчання в } \\
\text { цифровий інтерактивний досвід, активно використовуючи елементи } \\
\text { гейміфрікації. Завдання НR сьогодні - сфорормвати культуру, в якій кожен } \\
\text { співробітник буде зайнятий самонавчанням, здатний швидко переймати } \\
\text { знання та досвід колег і, разом з тим, готовий ділитися своїм власним } \\
\text { досвідом з іншими. Ринок праці стрімко змінюється, кидаючи нові виклики } \\
\text { всім, хто пов'язаний з управлінням персоналом. Змінюються парадигми і } \\
\text { стратегії, з'являються нові підходи в підборі, адаптації, навчання, мотивації } \\
\text { та інших НR ффункції. }\end{array}$ \\
\hline & $\begin{array}{l}\text { Трендь } \\
\text { праці }\end{array}$ & $\begin{array}{l}\text { Дедалі поширенішими стають такі тенденції, як } \\
\text { - Віддалений режим роботи, фрріланс } \\
\text { - Паралельна робота, друга кар'єра } \\
\text { - Поява «гібридних кар'єр» - використання в роботі навичок з різних } \\
\text { професій } \\
\text { - Володіння синтетичними знаннями } \\
\text { - Поява великої кількості нових професій } \\
\text { - Неповна зайнятість і тимчасові трудові контракти }\end{array}$ \\
\hline
\end{tabular}


$\mathrm{HR}$ - це не тільки автоматизація та оцифровка традиційних фрункцій управління персоналом, а й модернізація цих функцій на основі нового цифрового ділового мислення 3 акцентом на людей і ефективність роботи, (табл. 2).

Область застосування цифрових технологій в управлінні людськими ресурсами на сьогоднішній день знаходиться в стадії фрормування і розвитку, що не дозволяє провести об'єктивний і глибокий аналіз наукового визначення «цифровізації HR» (цифрова трансформація в системі управління персоналом). Однак очевидно, що цифрові технології в системі управління людськими ресурсами можуть бути застосовні до будь-якого бізнеспроцесу, особливу важливість такі технології набувають при пошуку, найму, адаптації, заохочення і розвитку співробітників організації.

На наш погляд, цисррову трансформацію в системі управління персоналом можна визначити як процес впровадження і застосування цифрових технологій в сфреру управління людськими ресурсами організації 3 метою підвищення продуктивності праці. При цьому зростання продуктивності праці $\epsilon$ результатом успішності таких процесів, як рекрутмент (пошук) і адаптація співробітників, навчання та розвиток, управління і організація діяльності.

Висновки. Підсумовуючи наведене, необхідно відзначити, що інформаційно-цифррові технології викликають глибокі зміни в структурі і характері сучасного ринку товарів і послуг, що обумовлює необхідність розвитку цисррової активності організацій. Основний акцент при фрормуванні цифррового середовища організації робиться на створення цифрової інсрраструктури, проте слід зазначити, що не менш важливу роль відіграє оновлення знань персоналу, створення системи та культури використання інформаційно-комунікаційних технологій, формування цифррових компетенцій персоналу, це розглядає сореру виробництва товарів і послуг як сореру практичної реалізації людського інтелекту, де домінуючим і пріоритетним ресурсом є знання, котрі стають новою актуальною основою конкурентоспроможної діяльності економічних суб'єктів у сучасному глобальному господарстві.

У системі соціально-економічного розвитку країни, знання як соціальний ресурс праці $€$ одним із найважливіших критеріїв оцінки раціональності, в тому числі ефективності організації суспільно-економічної системи країни.

У свою чергу головним завданням управління персоналом в умовах цифрровізації $€$ забезпечення ефективної діяльності співробітників і підвищення продуктивності праці з метою переходу організації на новий шлях розвитку і підвищення її цифрровий активності. Крім того, HR-служба сучасної компанії повинна бути вписана в ії цисррову культуру, фрокусуватися на співробітниках і індивідуальних

Трансформація функцій управління персоналом з використанням Digital-технологій

\begin{tabular}{|c|c|}
\hline Функції HR & Digital-технології \\
\hline $\begin{array}{l}\text { Стратегічне і кадрове планування; } \\
\text { HR-брендинг }\end{array}$ & $\begin{array}{l}\text { Платформа HR-бренду; HR-аналітика; } \\
\text { Прогнозуюча HR-аналітика; HR BigData (великі дані). }\end{array}$ \\
\hline $\begin{array}{l}\text { Підбір і відбір персоналу; } \\
\text { Маркетинг персоналу; } \\
\text { Адаптація персоналу }\end{array}$ & $\begin{array}{l}\text { E-Staff Recruiter (автоматизація підбору } \\
\text { персоналу); ATS (система управління } \\
\text { кандидатами); Соціальний рекрутинг; Онлайн } \\
\text { оцінка; Блокчейн; Платформи відбору кандидатів; } \\
\text { Чат-боти; Штучний інтелект; Відео інтерв'ю (VCV). }\end{array}$ \\
\hline $\begin{array}{l}\text { Управління талантами; } \\
\text { Навчання персоналу; } \\
\text { Управління кар'єрою персоналу; } \\
\text { Розвиток творчої та інтелектуальної } \\
\text { діяльності персоналу } \\
\text { Управління персоналом; } \\
\text { Корпоративна культура }\end{array}$ & $\begin{array}{l}\text { TMS (системи управління талантами); } \\
\text { LMS (системи управління електронним навчанням); } \\
\text { Machine Learning (машинне навчання); } \\
\text { Гейміфікація; } \\
\text { Віртуальні заняття; } \\
\text { Мобільне навчання; } \\
\text { Дрони }\end{array}$ \\
\hline $\begin{array}{l}\text { Мотивація і стимули; } \\
\text { Індивідуальне управління ефрективністю; } \\
\text { Зайнятість персоналу; } \\
\text { Організація праці; } \\
\text { Управління лояльністю персоналу }\end{array}$ & $\begin{array}{l}\text { DW (віртуальне робоче місце); } \\
\text { PM (управління результативністю); } \\
\text { Платорорми для роботи з віддаленими } \\
\text { співробітниками, співробітниками з частковою } \\
\text { зайнятістю і фррілансерами }\end{array}$ \\
\hline Управління персоналом & $\begin{array}{l}\text { HRM (управління персоналом); SAP ERP HCM; } \\
\text { HR-аналітика, HR BigData; CHIP (когнітивний } \\
\text { інтердрейс особистості) }\end{array}$ \\
\hline
\end{tabular}


траєкторіях їх розвитку, а також використовувати цифрові інструменти для управління навичками співробітників, їх навчання і мотивації. Використання аналітики великих даних може допомогти HR-служб в аналізі залученості співробітників в різні проекти організації, в пошуку талантів, у вимірі продуктивності різних підрозділів, а також, наприклад, для прогнозування звільнення кваліфікованих і ефрективних фрахівців або попередження їх профресійного вигорання. Цифрровізація, В першу чергу, дає можливість зняти численні рутинні завдання з співробітників, мінімізувавши ризик людської помилки і звільнивши фрахівцям час для вирішення більш важливих питань, дозволяючи більш ефективно використовувати знання і навички персоналу в рішенні бізнес-задач.

Перспективами подальших досліджень у цьому напрямку $€$ практичне впровадження HR - Digital з урахуванням специфріки діяльності підприємства, деталізація етапів впровадження системи діджиталізації та оцінювання його ефрективності.

\section{СПИСОК ВИКОРИСТАНИХ ДЖЕРЕЛ:}

1. Лапидус Л.В. Центр компетенций цифровой экономики. Ассоциация граждан и организаций по содействию развитию корпоративного образования. URL: http://www.makonews.ru/centr-kompetencijcifrovojekonomiki/

2. Силантьева О.О., Авхадеева Л.3., Нуретдинова Ю.В. Человеческий капитал в цифровой экономике. Вектор экономики. СМИ ЭЛ № ФС 77-66790, ISSN 2500-3666. 2019. № 6. 12 c. URL: www.vectoreconomy.ru

3. Грищук T. Как строить карьеру в третьем десятилетии XXI века. Екатеринбург, 2019. URL: https://hr-tv.ru/ speakers/tatjana-grishuk.html

4. Дедова Е. Циорровая экономика: тренды 2019 года. URL: http://www.lawfirm.ru/comments/index. php?id=19675

5. Тренды в HR 2019-2020. URL: https://smart-hr.com.ua/ru/news/trendy-v-hr-2019-2020-1

6. HR Digital: тренды и технологии 2019 года, о которых говорят HR-ы. URL: https://www.yandex.ru/ turbo?text=http\%3A\%2F\%2Fhr-elearning.ru\%2Fhr-digital-trendy-i-tekhnologii2019-goda-o-kotorykh-govoryat-hr\%2F

\section{REFERENCES:}

1. Lapidus L.V. Tsentr kompetentsiy tsifrovoy ekonomiki. Assotsiatsiya grazhdan i organizatsiy po Sodeystviye razvitiyu korporativnogo obrazovaniya. Retrieved from: http://www.makonews.ru/centr-kompetencij-cifrovojekonomiki/

2. Silant'yeva O.A., Avkhadeyeva L.Z., Nuretdinova Yu.V. (2019) Chelovecheskiy kapital v tsifrovoy ekonomike. Vektor ekonomiki. SMI EL № FS 77-66790, ISSN 2500-3666. No. 6, 12 p. Retrieved from: www.vectoreconomy.ru

3. Grishchuk T. (2019) Kak stroit ka'yeru v tretyem desyatiletii XXI veka. Yekaterinburg. Retrieved from: https://hr-tv.ru/speakers/tatjana-grishuk.html

4. Dedova E. Tsifrovaya ekonomika: trendy 2019 goda. Retrieved from: http://www.lawfirm.ru/comments/index. php?id=19675

5. Trendy v HR 2019-2020. Retrieved from: https://smart-hr.com.ua/ru/news/trendy-v-hr-2019-2020-1

6. HR Digital: trendy i tekhnologii 2019 goda, v kotorykh govoryat HR-y. Retrieved from: https://www.yandex.ru/ turbo?text=http\%3A\%2F\%2Fhr-elearning.ru\%2Fhr-digital-trendy-i-tekhnologii2019-goda-o-kotorykh-govoryat-hr\%2F 